\title{
PENGARUH PERAN ACCOUNT REPRESENTATIVE (AR) DAN SANKSI PAJAK TERHADAP KEPATUHAN WAJIB PAJAK ORANG PRIBADI (Studi Pada KPP Pratama Kendari)
}

\author{
Muntu Abdullah $^{1}$, Yuli Lestari Labangu ${ }^{2}$, Akilla Fadia Haya ${ }^{3}$ \\ Jurusan Akuntansi Fakultas Ekonomi dan Bisnis Universitas Halu Oleo Kendari \\ Sulawesi Tenggara
}

\begin{abstract}
ABSTRAK
Penelitian ini bertujuan untuk mengetahui pengaruh peran Account Representative dan Sanksi Pajak terhadap kepatuhan wajib pajak orang pribadi pada KPP Pratama Kendari. Data yang digunakan dalam penelitian ini adalah data kualitatif dan kuantitatif. Populasi penelitian ini adalah wajib pajak orang pribadi sebanyak 148.428 wajib pajak. Penentuan sampel dilakukan dengan sampling insidental, dihitung berdasarkan rumus slovin dan sampel sebanyak 100 repsonden. Pengumpulan data dilakukan menggunakan kuisioner. Metode analisis yang digunakan adalah metode analisis regresi linear berganda. Hasil dari penelitian ini menunjukan bahwa peran Account Representative berpengaruh signifikan terhadap kepatuhan wajib pajak orang pribadi, Sanksi Pajak berpengaruh signifikan terhadap kepatuhan wajib pajak orang pribadi, dan secara simultan peran Account Representative dan Sanksi Pajak berpengaruh signifikan terhadap kepatuhan wajib pajak orang pribadi pada KPP Pratama Kendari.
\end{abstract}

Kata Kunci : Account Representative, Sanksi Pajak, Kepatuhan Wajib Pajak.

\section{ABSTRACT}

This study aims to determine the effect of the role of the Account Representative and Tax Sanctions on the compliance of individual taxpayers at KPP Pratama Kendari. The data used in this research are qualitative and quantitative data. The population of this research is individual taxpayers as many as 148,428 taxpayers. The sample was determined by incidental sampling, calculated based on the Slovin formula and a sample of 100 respondents. Data collection was carried out using a questionnaire. The analytical method used is multiple linear regression analysis method. The results of this study indicate that the role of the Account Representative has a significant effect on individual taxpayer compliance, Tax Sanctions have a significant effect on individual taxpayer compliance, and simultaneously the role of Account Representatives and Tax Sanctions has a significant effect on individual taxpayer compliance at KPP Pratama Kendari. .

Keywords: Account Representative, Tax Penalty, Taxpayer Compliance

\section{PENDAHULUAN}

Indonesia merupakan salah satu negara berkembang. Berkembangnya indonesia memicu pemerintah untuk meningkatkan pembangunan dan infrastruktur negara, untuk 
Jurnal Akuntansi dan Keuangan (JAK)

Volume 6, No. 2 Oktober Tahun 2021

Page: 361 - 380

http://ojs.uho.ac.id/index.php/jak-uho/issue/archive

e-ISSN: $2088-4656$

meningkatkan pembangunan tersebut pemerintah membutuhkan biaya yang tidaklah sedikit. Untuk dapat merealisasikan tujuan tersebut perlu banyak memperhatikan masalah pembiayaan pembangunan (Savitri dan Nuraini 2017). Salah satu sumber penerimaan negara yang sangat penting untuk pembiayaan pemerintah dan pembangunan adalah dari penerimaan pajak.

Pajak memiliki peran penting dalam sumber penerimaan negara, karena pendapatan terbesar negara datang dari sektor pajak. Pajak sendiri banyak memberikan kontribusi besar pada pembangunan ekonomi di Indonesia dan sumber dana yang penting bagi pembiayaan nasional. Sehingga dapat disimpulkan bahwa kontribusi penerimaan pajak sangatlah berpengaruh terhadap jalannya roda pemerintahan dan perekonomian bangsa. Dana tersebut yang kemudian akan didistribusikan untuk mendanai pembangunan demi terciptanya kemakmuran rakyat, mulai dari kesehatan, pendidikan, sektor industri dan juga perbankan. Kontribusi penerimaan pajak sendiri dapat ditingkatkan sejalan dengan peningkatan kepatuhan dari para wajib pajak itu sendiri dalam membayarkan pajak mereka.

Untuk dapat memperluas basis pajak tersebut, perlu juga dilakukan pelayanan prima yaitu dengan memberikan pelayanan sebaik-baiknya terhadap setiap wajib pajak baik yang sudah terdaftar maupun belum terdaftar sebagai wajib pajak, karena wajib pajak sebagai pihak yang dibutuhkan oleh aparat pajak sudah seharusnya memperoleh pelayanan dan pengawasan yang baik. Dengan Pelayanan dan pengawasan yang baik maka berpotensi untuk meningkatkan kepatuhan pajak. Menurut Restu (dalam Susmita \& Supadi, 2016) kepatuhan wajib pajak didefinisikan sebagai perilaku dari seorang pajak dalam melakukan semua kewajiban perpajakan dan menggunakan hak perpajakannya dengan tetap berpatokan kepada peraturan perundang-undangan perpajakan yang berlaku. Hal ini merupakan salah satu tugas yang harus dikerjakan sebaik-baiknya oleh Direktorat Jendral Pajak (DJP) untuk dapat mengoptimalkan penerimaan pajak. Untuk itu perlu dilakukan reformasi perpajakan yang dilakukan dari tahun ke tahun dengan tetap berasaskan pada keadilan sosial.

Adapun berdasarkan data yang diperoleh dari KPP Pratama Kendari mengenai jumlah wajib pajak Orang Pribadi yang terdaftar yaitu sebagai berikut : 
Tabel 1.1

Rasio Wajib Pajak Orang Pribadi yang Melapor SPT Tahun 2016 s.d 2019

\begin{tabular}{|c|c|c|c|c|}
\hline \multirow{2}{*}{ TAHUN } & $\begin{array}{c}\text { Wajib Pajak } \\
\text { Orang } \\
\text { pribadi Yang } \\
\text { Terdaftar }\end{array}$ & $\begin{array}{c}\text { Wajib Pajak Yang Melapor SPT } \\
\text { OP Non } \\
\text { Karyawan }\end{array}$ & \multirow{2}{*}{ OP Karyawan } & \\
\hline 2016 & 107.843 & 2.294 & 54.370 & $53 \%$ \\
\hline 2017 & 122.670 & 6.042 & 46.823 & $43 \%$ \\
\hline 2018 & 134.349 & 7.386 & 44.733 & $39 \%$ \\
\hline 2019 & 148.428 & 9.972 & 54.349 & $43 \%$ \\
\hline
\end{tabular}

Sumber : KPP Pratama Kendari 2020

Berdasarkan data diatas menunjukan bahwa tingkat kepatuhan wajib pajak orang pribadi pada KPP Pratama kendari masih rendah, hal tersebut karena jumlah wajib pajak orang pribadi yang terdaftar dan melapor masih sangat jauh perbandingannya. Dapat dilihat pada tabel 1.1 bahwa jumlah wajib pajak yang terdaftar setiap tahunnya mengalami peningkatan sedangkan untuk wajib pajak yang melapor SPT mengalami penurunan. Sehingga hal tersebut menyebabkan tingkat kepatuhan wajib pajak orang pribadi pada KPP Pratama Kendari masih terbilang cukup rendah.

Maka, tujuan dalam penelitian ini adalah agar dapat mengetahui seberapa berpengaruhnya peran Account Representative dan Sanksi pajak terhadap Kepatuhan Wajib Pajak orang pribadi pada KPP Pratama di Kota Kendari.

\section{LANDASAN TEORI DAN HIPOTESIS}

\section{Pengertian Pajak}

Definisi pajak menurut S.I Djajadinigrat dan Siti Resmi (2014: 1) "Pajak sebagai suatu kewajiban menyerahkan sebagian dari kekayaan ke kas negara yang disebabkan suatu keadaan, kejadian, dan perbuatan yang memberikan kedudukan tertentu, tetapi bukan sebagai hukuman, menurut peraturan yang ditetapkan pemerintah serta dapat dipaksakan, tetapi tidak ada jasa timbal balik dari negara secara langsung untuk memelihara kesejahteraan secara umum". 
Jurnal Akuntansi dan Keuangan (JAK)

Volume 6, No. 2 Oktober Tahun 2021

Page: 361 - 380

http://ojs.uho.ac.id/index.php/jak-uho/issue/archive

e-ISSN: $2088-4656$

\section{Jenis Pajak}

Jenis pajak menurut (Waluyo, 2017: 12) terdapat berbagai jenis pajak yang dapat dikelompokan menjadi tiga yaitu pengelompokan menurut golongan atau pembebanan menurut sifat dan menurut pemungut dan pengelolanya.

1. Menurut golongan atau pembebanan, dibagi menjadi berikut ini :

a. Pajak langsung, adalah pajak yang pembebanannya tidak dapat dilimpahkan pihak lain, tetapi harus menjadi beban langsung wajib pajak yang bersangkutan . contoh : pajak penghasilan.

b. Pajak tidak langsung, adalah pajak yang pembebanannya dapat dilimpahkan kepada pihak lain. Contoh : pajak pertambahan nilai.

2. Menurut sifat

Pembagian pajak menurut sifat dimaksudkan pembedaan dan pembagiannya berdasarkan ciri - ciri prinsip adalah sebagai berikut:

a. Pajak subjektif, adalah pajak yang pemungutannya/pengenaannya berpangkal atau berdasarkan pada subjeknya yang selanjutnya dicari syarat objektifnya dalam arti memperhatikan keadaan dari wajib pajak. Contoh : pajak penghasilan.

b. Pajak objektif, adalah pajak yang berpangkal atau berdasarkan pada objeknya, tanpa memperhatikan keadaan dari wajib pajak. Contoh : pajak pertambahan nilai dan pajak penjualan atas barang mewah

3. Menurut pemungut dan pengelolaannya, adalah sebagai berikut :

a. Pajak pusat, adalah pajak yang dipungut oleh pemerintah pusat dan digunakan untuk membiayai rumah tangga negara. Contoh : pajak penghasilan, pajak pertambahan nilai, dan pajak penjualan atas barang mewah, pajak bumi dan bangunan, dan biaya materai.

b. Pajak daerah, adalah pajak yang dipungut oleh pemerintah daerah dan digunakan untuk membiayai rumah tangga daerah. Contoh : pajak reklame, pajak hiburan, biaya perolehan hak atas tanah dan bangunan (BPHTB), pajak bumi dan bangunan sektor perkotaan dan pedesaan (PBB P2). 
Jurnal Akuntansi dan Keuangan (JAK)

Volume 6, No. 2 Oktober Tahun 2021

Page: 361 - 380

http://ojs.uho.ac.id/index.php/jak-uho/issue/archive

e-ISSN: $2088-4656$

\section{Account Representative}

Menurut Diana Sari (2013) Account Representative adalah pegawai Direktorat Jenderal pajak yang diberikan wewenang khusus untuk memberikan pelayanan dan mengawasi wajib pajak secara langsung, dengan adanya Account Representative ini diharapkan dapat menciptakan hubungan yang dilandaskan kepercayaan anatara KPP dan wajib pajak. Adapun tugas Account Representative adalah :

1. Melakukan pengawasan kepatuhan perpajakan wajib pajak

2. Bimbingan / himbauan dan konsultasi teknis perpajakan kepada wajib pajak

3. Penyusunan profil wajib pajak

4. Analisis kinerja wajib pajak, rekonsiliasi data wajib pajak dalam rangka intensifikasi

5. Melakukan evaluasi hasil banding berdasarkan kepatuhan yang berlaku.

Dapat di lihat dari tugas - tugas AR tersebut, bahwa pada dasarnya tugas utama AR adalah :

1. Pengawasan kepatuhan wajib pajak (material/formal)

2. Konsultasi dan pelayanan

3. Penggalian potensi dan intensifikasi

4. Pengumpulan dan pengelolaan data / informasi.

\section{Sanki Pajak}

Menurut Aristanti Widyaningsi (2013) "sanksi berupa administrasi dan pidana yang dikenakan terhadap setiap orang ynag melakukan pelanggaran perpajakan yang secara nyata telah diatur dalam undang - undang”. Winerungan (2013) mengemukakan bahwa pengetahuan mengenai sanksi perpajakan sangat diperlukan. Untuk memaksimalkan penerimaan pajak, maka setiap wajib pajak perlu mengetahui dan memahami sanksisanksi apa saja di dalam norma perpajakan yang akan mereka peroleh jika mereka melanggar norma perpajakan yang telah diatur oleh pemerintah, hal ini berpengaruh terhadap kepatuhan wajib pajak itu sendiri.

\section{Kepatuhan Wajib Pajak}

Kepatuhan pajak merupakan kepatuhan seseorang dalam hal ini adalah wajib pajak terhadap peraturan atau undang - undang perpajakan (Arum,2012). Menurut (Simon 
Jurnal Akuntansi dan Keuangan (JAK)

Volume 6, No. 2 Oktober Tahun 2021

Page: 361 - 380

http://ojs.uho.ac.id/index.php/jak-uho/issue/archive

e-ISSN: $2088-4656$

James dalam Guandi, 2005) "kepatuhan pajak (Tax Compliance) adalah wajib pajak yang mempunyai kesediaan untuk memenuhi kewajiban pajaknya sesuai dengan aturan yang berlaku tanpa perlu diadakannya pemeriksaan, investigasi (obtrusiver investigasi) peringatan, ataupun ancaman dalam penerapan sanksi baik hukum maupun administrasi.

\section{Pengujian Hipotesis}

Hipotesis merupakan dugaan sementara yang mungkin benar dan mungkin salah, sehingga dapat dianggap atau dipandang sebagai kesimpulan yang sifatnya sementara. Adapun hipotesis dalam penelitian ini adalah :

$\mathrm{H}_{1:}$ Peran Account Representative berpengaruh signifikan Terhadap Kepatuhan Wajib Pajak Orang Pribadi

\section{$\mathrm{H}_{2}$ : Sanksi Pajak berpengaruh signifikan Terhadap Keptuhan Wajib Pajak Orang Pribadi}

\section{$\mathrm{H}_{3}$ : Peran Account Representative dan Sanksi Pajak berpengaruh signifikan Terhadap Kepatuhan Wajib Pajak}

\section{METODE PENELITIAN}

Penelitian ini dilakukan pada KPP Pratama Kendari Jl. Sao - Sao No. 188, Bende, Kec Kadia, Kota Kendari, Sulawesi Tenggara 93111. objek penelitian ini adalah Peran Account Representative $\left(\mathrm{X}_{1}\right)$, Sanksi Pajak $\left(\mathrm{X}_{2}\right)$ sebagai variabel independen, dan Kepatuhan Wajib Pajak (Y) sebagai variabel dependen.

Populasi dalam penelitian ini adalah wajib pajak orang pribadi yang terdaftar pada KPP Pratama Kota Kendari sebanyak 148.428 wajib pajak. jumlah sampel yang diambil dalam penelitian ini yaitu sebanyak 100 wajib pajak orang pribadi, untuk menentukan jumlah sampel peneliti menggunakan rumus Slovin. Metode pengambilan sampel dalam penelitian ini adalah secara nonprobability sampling yaitu sampling insidental, adalah teknik penentuan sampel berdasarkan kebetulan, yaitu siapa saja yang secara kebetulan / insidental bertemu dengan peneliti dapat digunakan sebagai sampel, bila dipandang orang yang kebetulan ditemui cocok sebagai sumber data.

Dalam penelitian ini, peneliti menggunakan jenis data kuantatif, penelitian kuantitatif adalah penelitian dengan memperoleh data yang berbentuk angka atau data kualitatif yang diangkakan (Sugiyono, 2017). Sumber data yang akan digunakan dalam penelitian ini adalah Data Primer dan Data Sekunder. Data primer diperoleh dengan 
Jurnal Akuntansi dan Keuangan (JAK)

Volume 6, No. 2 Oktober Tahun 2021

Page: 361 - 380

http://ojs.uho.ac.id/index.php/jak-uho/issue/archive

e-ISSN: 2088-4656

menyebarkan kuisioner yang dibagikan kepada wajib pajak yang terdaftar di KPP Pratama Kota Kendari, sedangkan data sekunder yaitu diperoleh dari artikel, jurnal, dan penelitian - penelitian yang dilakukan sebelumnya.

Pengumpulan data dilakukan dengan menyebar kuesioner, kuisioner merupakan teknik pengumpulan data yang dilakukan dengan cara memberi seperangkat pertanyaan atau pertanyaan tertulis kepada responden untuk dijawab. Kuisioner sendiri adalah daftar pertanyaan yang harus dijawab oleh responden. Daftar pertanyaan yang diajukan dalam bentuk kuisioner dan responden diminta untuk menjawab sesuai dengan pendapat responden.

\section{HASIL PENELITIAN DAN PEMBAHASAN}

\section{Hasil Penelitian}

Pada penelitian ini terdapat tabel tingkat pengembalian kuisioner dan 5 karakteristik responden yang dimasukkan, yaitu Jenis kelamin, status, usia, dan lama menjadi wajib pajak. Karakteristik responden tersebut akan dijelaskan lebih lanjut pada tabel mengenai data responden sebagai berikut :

\section{Tingkat Pengembalian Kuisioner}

Tabel 4.1

\begin{tabular}{|l|c|c|}
\hline \multicolumn{1}{|c|}{ Keterangan } & Jumlah & Presentase \\
\hline Kuisioner yang disebar & 100 & $100 \%$ \\
\hline Kuisioner yang kembali & 100 & $100 \%$ \\
\hline Kuisioner yang dapat diolah & 100 & $100 \%$ \\
\hline
\end{tabular}

Tabel 4.2

Karakteristik Responden

\begin{tabular}{|c|c|c|}
\hline Jenis kelamin & Jumlah & Presentase \\
\hline Laki - laki & 53 & $53 \%$ \\
\hline Perempuan & 47 & $47 \%$ \\
\hline Jumlah & 100 & $100 \%$ \\
\hline Usia & Jumlah & Presentase \\
\hline $20-30$ tahun & 29 & $29 \%$ \\
\hline $31-40$ tahun & 33 & $33 \%$ \\
\hline $41-50$ tahun & 32 & $32 \%$ \\
\hline$>50$ tahun & 6 & $6 \%$ \\
\hline Jumlah & 100 & $100 \%$ \\
\hline
\end{tabular}


Jurnal Akuntansi dan Keuangan (JAK)

Volume 6, No. 2 Oktober Tahun 2021

Page: 361 - 380

http://ojs.uho.ac.id/index.php/jak-uho/issue/archive

e-ISSN: 2088-4656

\begin{tabular}{|c|c|c|}
\hline Tingkat Pendidikan & Jumlah & Presentase \\
\hline D3 & 12 & $12 \%$ \\
\hline S1 & 42 & $42 \%$ \\
\hline S2 & 31 & $31 \%$ \\
\hline Lainnya & 15 & $15 \%$ \\
\hline Jumlah & 100 & $100 \%$ \\
\hline Lama Menjadi Wajib Pajak & Jumlah & Presentase \\
\hline $1-5$ tahun & 58 & $58 \%$ \\
\hline 6 - 10 tahun & 30 & $30 \%$ \\
\hline-15 tahun & 10 & $10 \%$ \\
\hline$>15$ tahun & 2 & $2 \%$ \\
\hline Jumlah & 100 & $100 \%$ \\
\hline
\end{tabular}

Sumber: Data primer yang diolah 2021

\section{Metode Analisis Data}

\section{Analisis Statistik Deskriptif}

Analisis statistik deskriptif dilakukan untuk mengetahui gambaran atau deskripsi suatu data (Ghozali, 2014). Dalam penelitian ini, analisis statistik deskriptif dapat dilihat dari nilai minimum, maksimum, rata - rata (mean), dan standar deviasi.

\section{Tabel 4.3}

Descriptive Statistics

\begin{tabular}{|l|r|r|r|r|r|}
\hline & $\mathrm{N}$ & \multicolumn{1}{c|}{$\begin{array}{c}\text { Minimu } \\
\mathrm{m}\end{array}$} & $\begin{array}{c}\text { Maximu } \\
\mathrm{m}\end{array}$ & \multicolumn{1}{c|}{ Mean } & $\begin{array}{c}\text { Std. } \\
\text { Deviation }\end{array}$ \\
\hline Account & 100 & 23,00 & 35,00 & 29,1600 & 2,83100 \\
Representative & 100 & 25,00 & 40,00 & 32,2400 & 4,02798 \\
Sanksi Pajak & 100 & 23,00 & 35,00 & 28,8400 & 3,56957 \\
Kepatuhan & 100 & & & & \\
Wajib Pajak & & & & \\
Valid N & & & & \\
(listwise) & 100 & & \\
\hline
\end{tabular}

\section{Pengujian Instrumen Penelitian}

\section{Uji Validitas}

Uji validitas digunakan untuk mengukur sah atau valid tidaknya suatu kuisioner. Suatu kuisioner dinyatakan valid jika, pertanyaan pada kuisioner mampu untuk mengungkapkan sesuatu yang akan diukur oleh kuesioner tersebut. Dalam hal ini, koefisien yang nilai signifikannya lebih kecil dari 5\% (level of significance) 
Jurnal Akuntansi dan Keuangan (JAK)

Volume 6, No. 2 Oktober Tahun 2021

Page: 361 - 380

http://ojs.uho.ac.id/index.php/jak-uho/issue/archive

e-ISSN: $2088-4656$

menunjukkan bahwa pertanyaan-pertanyaan tersebut sudah valid, sebagai pembentuk indikator (Ghozali, 2011).

Tabel 4.4

\begin{tabular}{|c|c|c|c|c|}
\hline Variabel & $\begin{array}{c}\text { Item } \\
\text { pertanyaan }\end{array}$ & $\begin{array}{c}\text { Koefisien } \\
\text { korelasi }\end{array}$ & Sig. & Ket. \\
\hline \multirow{7}{*}{$\begin{array}{l}\text { Peran Account } \\
\text { Representativ } \\
e(\mathrm{X} 1)\end{array}$} & X1.1.1 & 0.831 & 0,00 & Valid \\
\hline & $\mathrm{X} 1.1 .2$ & 0,836 & 0,00 & Valid \\
\hline & $\mathrm{X} 1.2 .1$ & 0,844 & 0,00 & Valid \\
\hline & $\mathrm{X} 1.2 .2$ & 0,832 & 0,00 & Valid \\
\hline & $\mathrm{X} 1.3 .1$ & 0,832 & 0,00 & Valid \\
\hline & X1.3.2 & 0,781 & 0,00 & Valid \\
\hline & $\mathrm{X} 1.3 .3$ & 0,719 & 0,00 & Valid \\
\hline \multirow{8}{*}{$\begin{array}{l}\text { Sanksi Pajak } \\
\text { (X2) }\end{array}$} & $\mathrm{X} 2.1 .1$ & 0,881 & 0,00 & Valid \\
\hline & $\mathrm{X} 2.1 .2$ & 0,882 & 0,00 & Valid \\
\hline & $\mathrm{X} 2.2 .1$ & 0,860 & 0,00 & Valid \\
\hline & $\mathrm{X} 2.2 .2$ & 0,876 & 0,00 & Valid \\
\hline & $\mathrm{X} 2.3 .1$ & 0,868 & 0,00 & Valid \\
\hline & $\mathrm{X} 2.3 .2$ & 0,875 & 0,00 & Valid \\
\hline & X2.4.1 & 0,882 & 0,00 & Valid \\
\hline & $\mathrm{X} 2.4 .2$ & 0,867 & 0,00 & Valid \\
\hline \multirow{7}{*}{$\begin{array}{l}\text { Kepatuhan } \\
\text { Wajib Pajak } \\
\text { (Y) }\end{array}$} & Y1.1.1 & 0,886 & 0,00 & Valid \\
\hline & Y1.1.2 & 0,875 & 0,00 & Valid \\
\hline & Y1.2.1 & 0,935 & 0,00 & Valid \\
\hline & Y1.2.2 & 0,938 & 0,00 & Valid \\
\hline & Y1.3.1 & 0,862 & 0,00 & Valid \\
\hline & Y1.3.2 & 0,853 & 0,00 & Valid \\
\hline & Y1.3.3 & 0,721 & 0,00 & Valid \\
\hline
\end{tabular}

Sumber: Data primer yang diolah 2021

Dari tabel diatas disimpulkan bahwa seluruh item pernyataan yang digunakan dalam penelitian ini adalah valid. Hal tersebut dapat dilihat dari masing -masing item pernyataan yang memiliki nilai alpa (a) kurang dari 0,05 serta memiliki nilai koefisien 
Jurnal Akuntansi dan Keuangan (JAK)

Volume 6, No. 2 Oktober Tahun 2021

Page: 361 - 380

http://ojs.uho.ac.id/index.php/jak-uho/issue/archive

e-ISSN: 2088-4656

korelasi positif dan lebih besar daripada r-tabel 0,195 , hal ini berarti bahwa data yang diperoleh telah valid dan dapat dilakukan pengujian lebih lanjut.

\section{Uji Reabilitas}

Ghozali (2011:47) menyatakan bahwa reliabilitas sebenarnya adalah alat untuk mengukur suatu kuesioner yang merupakan indikator dan variabel atau konstruksi. suatu kuesioner dikatakan reliabel ketika jawaban responden konsisten dari waktu ke waktu.

Tabel 4.5

\begin{tabular}{|c|c|c|c|}
\hline Variabel & Item Pernyataan & Cronbach's Alpha & Ket. \\
\hline \multirow{7}{*}{$\begin{array}{l}\text { Peran Account } \\
\text { Representative } \\
\quad \text { (X1) }\end{array}$} & $\mathrm{X} 1.1 .1$ & \multirow{2}{*}{0,853} & \multirow{2}{*}{ Reliabel } \\
\hline & $\mathrm{X} 1.1 .2$ & & \\
\hline & $\mathrm{X} 1.2 .1$ & \multirow{2}{*}{0,859} & \multirow{2}{*}{ Reliabel } \\
\hline & $\mathrm{X} 1.2 .2$ & & \\
\hline & $\mathrm{X} 1.3 .1$ & \multirow{3}{*}{0,837} & \multirow{3}{*}{ Reliabel } \\
\hline & $\mathrm{X} 1.3 .2$ & & \\
\hline & $\mathrm{X} 1.3 .3$ & & \\
\hline \multirow{8}{*}{$\begin{array}{l}\text { Sanksi Pajak } \\
\text { (X2) }\end{array}$} & $\mathrm{X} 2.1 .1$ & \multirow{2}{*}{0,904} & \multirow{2}{*}{ Reliabel } \\
\hline & $\mathrm{X} 2.1 .2$ & & \\
\hline & $\mathrm{X} 2.2 .1$ & \multirow{2}{*}{0,891} & \multirow{2}{*}{ Reliabel } \\
\hline & $\mathrm{X} 2.2 .2$ & & \\
\hline & $\mathrm{X} 2.3 .1$ & \multirow{2}{*}{0,894} & \multirow{2}{*}{ Reliabel } \\
\hline & $\mathrm{X} 2.3 .2$ & & \\
\hline & $\mathrm{X} 2.4 .1$ & \multirow{2}{*}{0,897} & \multirow{2}{*}{ Reliabel } \\
\hline & $\mathrm{X} 2.4 .2$ & & \\
\hline \multirow{7}{*}{$\begin{array}{c}\text { Kepatuhan } \\
\text { Wajib Pajak (Y) }\end{array}$} & Y1.1.1 & \multirow{2}{*}{0,903} & \multirow{2}{*}{ Reliabel } \\
\hline & Y1.1.2 & & \\
\hline & Y1.2.1 & \multirow{2}{*}{0,953} & \multirow{2}{*}{ Reliabel } \\
\hline & Y1.2.2 & & \\
\hline & Y1.3.1 & \multirow{3}{*}{0,872} & \multirow{3}{*}{ Reliabel } \\
\hline & Y1.3.2 & & \\
\hline & Y1.3.3 & & \\
\hline
\end{tabular}

Sumber: Data primer yang diolah 2021

Dapat dilihat dari tabel diatas, dapat disimpulkan bahwa variabel-variabel yang digunakan dalam penelitian ini reliabel, karena keseluruhan variabel memiliki nilai cronbach's alpha yang lebih besar dari 0,60. Sehingga variabel-variabel tersebut layak untuk digunakan sebagai alat ukur instrumen kuisioner dalam penelitian ini. 
Jurnal Akuntansi dan Keuangan (JAK)

Volume 6, No. 2 Oktober Tahun 2021

Page: 361 - 380

http://ojs.uho.ac.id/index.php/jak-uho/issue/archive

e-ISSN: 2088-4656

\section{Uji Analisis Faktor}

Uji analisis faktor adalah uji yang digunakan untuk melihat faktor mana dari indikator - indikator yang ada pada sebuah variabel yang dominan mempengaruhi terbentuknya variabel tersebut.

\section{Variabel Peran Account Representative (X1)}

Tabel 4.6

Hasil uji analisis faktor variabel peran Account Representative X1

\begin{tabular}{|l|l|c|c|c|}
\hline No & \multicolumn{1}{|c|}{ Indikator } & Loading Factor & KMO MSA & Sig \\
\hline $\mathbf{1}$ & $\begin{array}{l}\text { Berkomunikasi dengan baik } \\
\text { kepada wajib pajak (X1.1) }\end{array}$ & $\mathbf{0 , 5 3 5}$ & \multirow{2}{*}{$\mathbf{0 , 6 3 2}$} & $\mathbf{0 , 0 0}$ \\
\cline { 1 - 3 } & $\begin{array}{l}\text { Mengawasi pemenuhan } \\
\text { kewajiban perpajakan wajib } \\
\text { pajak (X1.2) }\end{array}$ & $\mathbf{0 , 5 6 1}$ & \\
\cline { 1 - 3 } & $\begin{array}{l}\text { Memberikan pelayanan } \\
\text { prima (X1.3) }\end{array}$ & $\mathbf{0 , 5 3 0}$ & \\
\hline
\end{tabular}

Sumber: Data primer yang diolah 2021

\section{Variabel Sanksi Pajak (X2)}

Tabel 4.7

Hasil uji analisis faktor variabel sanksi pajak X2

\begin{tabular}{|c|c|c|c|c|}
\hline No & Indikator & $\begin{array}{c}\text { Loading } \\
\text { Factor }\end{array}$ & KMO MSA & Sig \\
\hline 1 & $\begin{array}{l}\text { Sanksi pajak sangat } \\
\text { diperlukan (X2.1) }\end{array}$ & 0,637 & \multirow{4}{*}{$\mathbf{0 , 8 1 7}$} & \multirow{4}{*}{$\mathbf{0 , 0 0}$} \\
\hline 2 & $\begin{array}{l}\text { Sanksi dilaksanakan dengan } \\
\text { tegas (X2.2) }\end{array}$ & 0,736 & & \\
\hline 3 & $\begin{array}{l}\text { Sanksi sesuai dengan besar } \\
\text { kecilnya pelanggaran }(\mathrm{X} 2.3)\end{array}$ & 0,775 & & \\
\hline 4 & $\begin{array}{l}\text { Sanksi sesuai dengan } \\
\text { ketentuan dan peraturan } \\
\text { yang berlaku (X2.4) }\end{array}$ & $\mathbf{0 , 8 0 4}$ & & \\
\hline
\end{tabular}

Sumber: Data primer yang diolah 2021 
Jurnal Akuntansi dan Keuangan (JAK)

Volume 6, No. 2 Oktober Tahun 2021

Page: 361 - 380

http://ojs.uho.ac.id/index.php/jak-uho/issue/archive

e-ISSN: 2088-4656

\section{Variabel Kepatuhan Wajib Pajak (Y)}

Tabel 4.8

Hasil uji analisis faktor variabel kepatuhan wajib pajak Y1

\begin{tabular}{|l|l|c|c|c|}
\hline No & \multicolumn{1}{|c|}{ Indikator } & Loading Factor & KMO MSA & Sig \\
\hline $\mathbf{1}$ & $\begin{array}{l}\text { Kepatuhan wajib pajak dalam } \\
\text { mendaftarkan diri (Y1.1) }\end{array}$ & $\mathbf{0 , 7 8 3}$ & \multirow{2}{*}{$\mathbf{0 , 7 3 9}$} & $\mathbf{0 , 0 0}$ \\
\hline $\mathbf{2}$ & $\begin{array}{l}\text { Kepatuhan dalam menghitung } \\
\text { dan membayar pajak terutang } \\
\text { (Y1.2) }\end{array}$ & $\begin{array}{l}\mathbf{0 , 7 9 3} \\
\text { kepatuhan untu melaporkan } \\
\text { (Y1.3) }\end{array}$ & $\mathbf{0 , 7 9 5}$ & \\
\hline $\mathbf{3}$ & \begin{tabular}{l} 
kembali surat pemberitahuan \\
\hline
\end{tabular}
\end{tabular}

Sumber: Data primer yang diolah 2021

Hasil uji analisis faktor untuk ketiga variabel diatas menunjukan nilai signifikansi, 0,000 yang berarti bahwa seluruh indikator yang ada pada setiap variabel sangat berarti terhadap variabel tersebut. Jika dilihat dari nilai uji KMO MSA seluruh variabel dalam penelitian ini menunjukan nilai $>0,50$ artinya proses analisis seluruh indikator pada setiap variabel dapat dilanjutkan.

\section{Hasil Uji Asumsi Klasik}

\section{Uji Normalitas}

Uji normalitas bertujuan untuk menguji apakah didalam model regresi, variabel terikat dan variabel bebas mempunyai distribusi normal atau tidak.

Tabel 4.9

Hasil Uji Normalitas One-Sample Kolmogrov-Smirnov Test One-Sample Kolmogorov-Smirnov Test

\begin{tabular}{|ll|r|}
\hline & & $\begin{array}{r}\text { Unstandardiz } \\
\text { ed Residual }\end{array}$ \\
\hline $\mathrm{N}$ & & 100 \\
Normal Parameters & Mean &, 0000000 \\
& Std. &, 41009826 \\
Most Extreme & Deviation &, 054 \\
Differences & Absolute &, 044 \\
& Positive &,- 054 \\
Test Statistic & Negative &, 054 \\
Asymp. Sig. (2-tailed) & &, 200 \\
\hline
\end{tabular}

Sumber output spss 21(2021) 
Jurnal Akuntansi dan Keuangan (JAK)

Volume 6, No. 2 Oktober Tahun 2021

Page: $361-380$

http://ojs.uho.ac.id/index.php/jak-uho/issue/archive

e-ISSN: $2088-4656$

Berdasarkan tabel diatas menunjukan bahwa hasil Asymp sig (2-Tailed) sebesar 0,200 . Nilai tersebut memenuhi syarat normalitas yaitu lebih besar dari 0,50 sehingga dapat disimpulkan bahwa data variabel dalam penelitian ini memiliki distribusi yang normal.

\section{Uji Multikolinearitas}

Uji multikolinearitas bertujuan untuk menguji apakah dalam model regresi ditemukan adanya korelasi antar variabel bebas. Model regresi yang baik seharusnya tidak terjadi korelasi diantara variabel bebas (Ghozali, 2011).

Tabel 4.10

Coefficients $^{\mathrm{a}}$

\begin{tabular}{|c|c|c|c|c|c|c|c|}
\hline \multirow[b]{2}{*}{ Model } & \multicolumn{2}{|c|}{$\begin{array}{c}\text { Unstandardized } \\
\text { Coefficients }\end{array}$} & \multirow{2}{*}{$\begin{array}{c}\text { Standardized } \\
\text { Coefficients } \\
\text { Beta }\end{array}$} & \multirow[b]{2}{*}{$\mathrm{T}$} & \multirow[b]{2}{*}{ Sig. } & \multicolumn{2}{|c|}{$\begin{array}{c}\text { Collinearity } \\
\text { Statistics }\end{array}$} \\
\hline & B & $\begin{array}{l}\text { Std. } \\
\text { Error }\end{array}$ & & & & Tolerance & VIF \\
\hline 1 (Constant) & 1,020 & ,464 & & 2,197 & ,030 & & \\
\hline $\begin{array}{l}\text { Peran Account } \\
\text { Representative }\end{array}$ & ,246 & , 112 & , 194 & 2,201 & ,030 & 840 & 1,191 \\
\hline Sanksi Pajak &, 515 & ,090 &, 503 & 5,707 & ,000 & 840 & 1,191 \\
\hline
\end{tabular}

a. Dependent Variable: Y1

Sumber output spss 21(2021)

Berdasarkan tabel diatas, dapat dilihat bahwa nilai (VIF) masing-masing variabel bebas lebih kecil dari 10 dan nilai tolerance lebih besar dari 0,10, Dengan demikian dapat disimpulkan jika model regresi tersebut terbebas dari asumsi multikolinearitas.

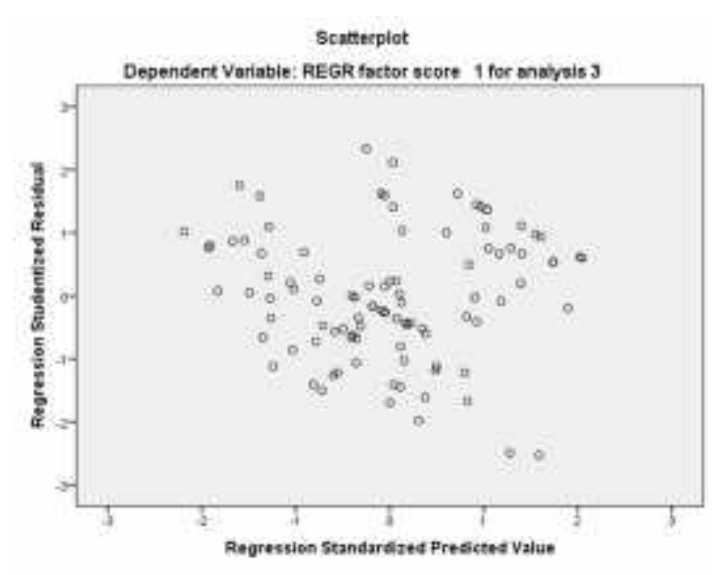

\section{Uji Heterokedastisitas}

Uji heteroskedastisitas bertujuan untuk menguji apakah dalam model regresi terjadi ketidaksamaan variance dari residul suatu pengamatan ke pengamatan yang lain.(Gunawan, 2016).

Berdasarkan tabel disamping menunjukan pola penyebarannya, dimana titik-titik menyebar secara acak dan tidak 
Jurnal Akuntansi dan Keuangan (JAK)

Volume 6, No. 2 Oktober Tahun 2021

Page: 361 - 380

http://ojs.uho.ac.id/index.php/jak-uho/issue/archive

e-ISSN: 2088-4656

menunjukan adanya suatu pola tertentu. Sehingga dapat disimpulakan bahwa dalam model regresi tersebut tidak terdapat asumsi heterokedastisitas.

\section{Uji Autokorelasi}

Menurut Azuar Juliandi, dkk. (2014) “ Autokorelasi bertujuan untu menguji apakah dalam sebuah model regresi linear ada korelasi antara kesalahan pengganggu pada periode $t$ dengan kesalahan pada periode $\mathrm{t}-1$ (sebelumnya)".

Tabel 4.12

Model Summary ${ }^{b}$

\begin{tabular}{|l|r|r|r|r|r|}
\hline Model & R & R Square & $\begin{array}{c}\text { Adjusted R } \\
\text { Square }\end{array}$ & $\begin{array}{c}\text { Std. Error of } \\
\text { the Estimate }\end{array}$ & $\begin{array}{c}\text { Durbin- } \\
\text { Watson }\end{array}$ \\
\hline 1 &, $607^{\mathrm{a}}$ &, 368 &, 355 &, 41430 & 1,748 \\
\hline
\end{tabular}

Sumber output spss 21(2021)

Berdasarkan tabel diatas, diperoleh D-W sebesar 1,748. Angka ini terletak diantara -2 dan +2 yang berarti tidak ada autokorelasi positif maupun negative.

\section{Analisis Data Dan Pengujian Hipotesis}

\section{Analisis Regresi Linear Beraganda}

Analisi regresi berganda merupakan analisis yang digunakan untuk menghubungkan atara suatu variabel dependen dengan dua atau lebih variabel independen. Dajan (1996).

Tabel 4.13

Coefficients $^{\text {a }}$

\begin{tabular}{|c|c|c|c|c|c|}
\hline \multirow[b]{2}{*}{ Model } & \multicolumn{2}{|c|}{$\begin{array}{l}\text { Unstandardized } \\
\text { Coefficients }\end{array}$} & \multirow{2}{*}{$\begin{array}{c}\text { Standardized } \\
\text { Coefficients }\end{array}$} & \multirow[b]{2}{*}{$\mathrm{T}$} & \multirow[b]{2}{*}{ Sig. } \\
\hline & B & Std. Error & & & \\
\hline $\begin{array}{ll}\text { (Constant } \\
\end{array}$ & 1,020 & ,464 & & 2,197 & ,030 \\
\hline $\mathrm{X} 1$ & ,246 &, 112 & , 194 & 2,201 &, 030 \\
\hline $\mathrm{X} 2$ &, 515 & ,090 & ,503 & 5,707 &, 000 \\
\hline
\end{tabular}

Sumber output spss 21(2021)

Berdasarkan tabel diatas, maka dapat diperoleh persamaan sebagai berikut :

$$
Y=1,020+0,246 X_{1}+0,515 X_{2+} e
$$

Berdasarkan persamaan regresi diatas, Konstanta bernilai 1,020, hal ini menandakan jika pengaruh peran account representative dan sanksi pajak diasumsikan konstan atau 
Jurnal Akuntansi dan Keuangan (JAK)

Volume 6, No. 2 Oktober Tahun 2021

Page: 361 - 380

http://ojs.uho.ac.id/index.php/jak-uho/issue/archive

e-ISSN: $2088-4656$

sama dengan nol, maka variabel terikat kepatuhan wajib pajak akan mengalami kenaikan sebesar 1,020. Koefisien X1 sebesar 0,246, dapat diartikan bahwa apabila variabel independen peran account representative meningkat sebesar 1 dengan asumsi variabel independen lainnya konstan, maka variabel depnden kepatuhan wajib pajak akan meningkat sebesar 0,246. Koefisien X2 sebesar 0,515, dapat diartikan bahwa apabila variabel independen sanksi pajak meningkat sebesar 1 dengan asumsi variabel independen lainnya konstan, maka variabel dependen kepatuhan wajib pajak akan meningkat sebesar 0,515 .

\section{Pengujian Hipotesis}

\section{Uji $t$}

Uji $t$ dasarnya menunjukan seberapa jauh pengaruh satu variabel independen secara individual dalam menerangkan variasi variabel dependen (Ghozali, 2011).

Tabel 4.14

Coefficients $^{\mathrm{a}}$

\begin{tabular}{|l|r|r|r|c|c|}
\hline & \multicolumn{2}{|c|}{$\begin{array}{c}\text { Unstandardized } \\
\text { Coefficients }\end{array}$} & $\begin{array}{c}\text { Standardized } \\
\text { Coefficients }\end{array}$ & & \\
\cline { 2 - 5 } Model & \multicolumn{1}{|c|}{ B } & $\begin{array}{c}\text { Std. } \\
\text { Error }\end{array}$ & Beta & T & Sig. \\
\hline 1 (Constant) & 1,020 &, 464 & & 2,197 &, 030 \\
$\begin{array}{c}\text { Peran Account } \\
\text { Representative } \\
\text { Sanksi Pajak }\end{array}$ &, 246 &, 112 &, 194 & 2,201 &, 030 \\
\hline
\end{tabular}

Sumber output spss 21(2021)

Berdasarkan tabel diatas dapat disimpulkan :

\section{Pengujian Hipotesis Pertama}

Berdasarkan tabel di atas variabel Peran Account Representative memiliki nilai $t$ hitung sebesar 2,197>t-tabel yaitu sebesar 1,988 dan nilai koefisien regresi yang positif, sebesar 0,246 dan tingkat signifikansi sebesar 0,030 yang berarti bahwa nilai signifikansinya $<0,05$. Dari hasil tersebut maka dapat disimpulkan bahwa Peran Account Representative berpengaruh secara signifikan terhadap kepatuhan wajib pajak orang pribadi. Hal ini berarti bahwa semakin tinggi tingkat Peran account representative maka tingkat kepatuhan wajib pajak juga akan semakin meningkat pada KPP Pratama 
Jurnal Akuntansi dan Keuangan (JAK)

Volume 6, No. 2 Oktober Tahun 2021

Page: 361 - 380

http://ojs.uho.ac.id/index.php/jak-uho/issue/archive

e-ISSN: 2088-4656

Kendari. Maka $\mathrm{H}_{1}$ yang menyatakan bahwa peran account representative berpengaruh secara signifikan terhadap kepatuhan wajib pajak diterima.

\section{Pengujian Hipotesis Kedua}

Berdasarkan tabel diatas, variabel Sanksi Pajak memiliki nilai $t$-hitung sebesar 5,707 $>t$-tabel yaitu sebesar 1,988 dan nilai koefisiensi regresi yang positif sebesar 0,515 dan tingkat signifikansi sebesar 0,00 yang berarti bahwa nilai signifikansinya $<0,05$. Maka dapat disimpulkan bahwa sanksi pajak berpengaruh signifikan terhadap kepatuhan wajib pajak orang pribadi. Dengan demikian menunjukan bahwa semakin tinggi sanksi pajak maka kepatuhan wajib pajak juga akan meningkat. Maka $\mathrm{H}_{2}$ yang menyatakan bahwa sanksi pajak berpengaruh secara signifikan terhadap kepatuhan wajib pajak diterima.

\section{Uji $F$}

Uji $F$ pada dasarnya menunjukan apakah semua variabel independen yang dimasukkan dalam model mempunyai pengaruh secara simultan terhadap variabel dependen (Ghozali, 2011).

Tabel 4.15

ANOVA $^{\text {a }}$

\begin{tabular}{|ll|r|r|r|r|r|}
\hline \multicolumn{2}{|l|}{ Model } & \multicolumn{1}{|c|}{$\begin{array}{c}\text { Sum of } \\
\text { Squares }\end{array}$} & Df & Mean Square & F & Sig. \\
\hline 1 & Regression & 9,703 & 2 & 4,851 & 28,263 &, $000^{\mathrm{b}}$ \\
& Residual & 16,650 & 97 &, 172 & & \\
& Total & 26,353 & 99 & & & \\
\hline
\end{tabular}

Dari tabel diatas menunjukan bahwa nilai $F$-hitung sebesar 28,263 dengan nilai signifikansi sebesar 0,000, dan nilai signifikan tersebut lebih kecil dari 0,05 serta nilai $F$-hitung 28,263 lebih besar dari $F$-tabelnya sebesar 3,09. Sehingga dapat ditarik kesimpulan bahwa, Peran Account Representativ $\left(\mathrm{X}_{1}\right)$ dan Sanksi Pajak $\left(\mathrm{X}_{2}\right)$ secara bersama - sama berpengaruh terhadap Kepatuhan Wajib Pajak.

\section{Uji Koefisiensi Determinasi (R2)}

Pengujian koefisien determinasi dapat dilakukan jika hasil uji statistik- $F$ bernilai signifikan, koefisien determinas (R2) pada intinya mengukur seberapa jauh kemampuan model dalam menerangkan variasi variabel dependen. 
Jurnal Akuntansi dan Keuangan (JAK)

Volume 6, No. 2 Oktober Tahun 2021

Page: 361 - 380

http://ojs.uho.ac.id/index.php/jak-uho/issue/archive

e-ISSN: 2088-4656

Tabel 4.16

Model Summary

\begin{tabular}{|c|c|c|c|c|}
\hline Model & $\mathrm{R}$ & $\mathrm{R}$ Square & Adjusted R Square & $\begin{array}{c}\text { Std. Error of the } \\
\text { Estimate }\end{array}$ \\
\hline 1 &, $607^{\mathrm{a}}$ &, 368 &, 355 &, 41430 \\
\hline
\end{tabular}

Berdasarkan tabel diatas, disimpulkan bahwa besarnya koefisien determinasi yang disesuaikan ( $R$ Square) sebesar 0,368 menunjukan besarnya pegaruh langsung variabel peran account representative (X1) dan sanksi pajak pajak (X2) terhadap kepatuhan wajib pajak orang pribadi (Y) adalah sebesar 36,8\%. Hal ini berarti bahwa ada variabel lain atau variabel epselon $(€)$ sebesar $63,2 \%$ yang mempengaruhi variabel $\mathrm{Y}$ namun tidak diukur dalam penelitian.

\section{Pembahasan}

Hipotesis pertama $\left(\mathrm{H}_{1}\right)$ menyatakan bahwa Account Representative berpengaruh secara signifikan terhadap kepatuhan wajib pajak orang pribadi. Berdasarkan hasil analisis dapat dilihat dari hasil uji analisis faktor yang bernilai signifikan membentuk variabel peran Account Representative sehingga proses dari ketiga indikator tersebut dapat dilanjutkan. Adapun faktor yang paling membentuk variabel Account Representative adalah indikator kedua yaitu mengawasi pemenuhan kewajiban perpajakan wajib pajak dan untuk nilai terendah terdapat pada inikator ketiga yaitu memberikan pelayanan prima. Hal ini menunjukan bahwa semakin baik kinerja Account Repreentative maka wajib pajak akan lebih termotivasi untuk membayar pajak sehingga akan berdampak pada tingkat kepatuhan wajib pajak yang ada di KPP Pratama Kendari, yang artinya Account Representative di KPP Pratama Kendari sudah melakukan tugasnya dengan baik dalam membantu menyelesaikan permasalahan dan memberikan informasi mengenai perpajakan kepada wajib pajak yang ingin membayar pajak di KPP Pratama Kendari, dengan demikian hipotesis pertama diterima.

Hipotesis kedua $\left(\mathrm{H}_{2}\right)$ menyatakan bahwa sanksi pajak berpengaruh secara signifikan terhadap kepatuhan wajib pajak orang pribadi. Berasarkan Hasil analisis menunjukan bahwa variabel sanksi pajak memiliki nilai koefisien regresi yang menunjukkan bahwa sanksi pajak mempunyai arah yang positif terhadap kepatuhan 
Jurnal Akuntansi dan Keuangan (JAK)

Volume 6, No. 2 Oktober Tahun 2021

Page: 361 - 380

http://ojs.uho.ac.id/index.php/jak-uho/issue/archive

e-ISSN: $2088-4656$

wajib pajak dan pengaruhnya signifikan. selanjutnya dapat dilihat dari hasil uji analisis faktornya yang bernilai signifikan membentuk variabel sanksi pajak yang berarti proses keempat indikator dari variabel sanksi pajak dapat dilanjutkan. Adapun faktor yang paling membentuk variabel sanksi pajak adalah indikator keempat yaitu sanksi sesuai dengan ketentuan dan peraturan yang berlaku dan nilai terendah terdapat pada indikator pertama yaitu sanksi pajak sangat diperlukan. Sehingga apabila sanksi pajak semakin tinggi maka akan semakin meningkat kepatuhan wajib pajaknya. Hal ini berarti bahwa sanksi pajak berpengaruh signifikan terhadap kepatuhan wajib pajak di KPP Pratama Kendari.

Hipotesis ketiga $\left(\mathrm{H}_{3}\right)$ menyatakan bahwa Peran Account Representative dan Sanksi Pajak berpengaruh secara signifikan terhadap Kepatuhan Wajib Pajak Orang Pribadi. Hal ini dapat dilihat dari hasil uji $F$ (simultan) yang menunjukan bahwa nilainya signifikan sehingga dapat disimpulkan bahwa peran Account Representative dan Sanksi Pajak berpengaruh secara simultan terhadap kepatuhan wajib pajak orang pribadi. Hal ini berarti bahwa peran Account Representative dan penerapan sanksi pajak dapat mempengaruhi dan memberikan dampak terhadap peningkatan kepatuhan wajib pajak orang pribadi. Sehingga hipotesis diterima.

\section{KESIMPULAN, KETERBATASAN, IMPLIKASI DAN REKOMENDASI}

\section{Kesimpulan}

1. Berdasarkan hasil analisis yang dilakukan menunjukan bahwa peran Account Representative berpengaruh secara signifikan terhadap Kepatuhan Wajib Pajak Orang Pribadi pada KPP Pratama Kendari. Hal ini berarti bahwa semakin baik peran Account Representave dalam menjalankan tugasnya maka Kepatuhan Wajib Pajak akan semakin baik juga.

2. Berdasarkan hasil analisis menunjukan bahwa Sanksi Pajak berpengaruh secara signifikan terhadap Kepatuhan Wajib Pajak Orang Pribadi pada KPP Pratama Kendari. Hal ini berarti bahwa semakin tinggi sanksi yang diberikan kepada wajib pajak maka akan memberikan pengaruh dan meningkatakan kepatuhan wajib pajak. 
Jurnal Akuntansi dan Keuangan (JAK)

Volume 6, No. 2 Oktober Tahun 2021

Page: 361 - 380

http://ojs.uho.ac.id/index.php/jak-uho/issue/archive

e-ISSN: $2088-4656$

3. Berdasarkan hasil analisis menunjukan bahwa peran Account Representative dan sanksi pajak berpengaruh secara signifikan terhadap kepatuhan wajib pajak orang pribadi pada KPP Pratama Kendari. hal ini berarti bahwa peran account representative dan sanksi pajak dapat mempengaruhi dan memberikan dampak terhadap peningkatan kepatuhan wajib pajak orang pribadi pada KPP Pratama Kendari.

\section{Keterbatasan}

1. Subjek dalam penelitian ini hanya pada wajib pajak orang pribadi, diharapkan pada peneliti selanjutnya untuk menambah subjek penelitian pada wajib pajak badan.

2. Penelitian ini terbatas pada dua variabel independen saja, diharapkan pada peneliti selanjutnya untuk menambah variabel independen lainnya

\section{Implikasi}

Peran account representative dan sanksi pajak terbukti memberikan pengaruh terhadap kepatuhan wajib pajak orang pribadi. Oleh karena itu, apabila peran account representative dan sanksi pajak dijalankan dengan baik maka kepatuhan wajib pajak orang pribdi pada KPP Pratama Kendari akan meningkat.

\section{Rekomendasi}

1. Bagi pihak pegawai KPP Pratama Kendari diharapkan agar selalu memberikan pelayanan prima yaitu dengan memberikan pelayanan yang baik dan lebih baik lagi kepada wajib pajak, serta penerapan saksi pajak yang tegas sehingga timbul kesadaran wajib pajak untuk patuh dan taat terhadap kewajiban perpajakannya.

2. Untuk peneliti selanjutnya disarankan untuk memperluas lagi objek penelitian dan juga menambah variabel - variabel lain yang lebih berpengaruh terhadap tingkat kepatuhan wajib pajak agar hasil penelitian yang dilakukan lebih memuaskan.

\section{DAFTAR PUSTAKA}

Alfiansyah, Febri. 2012. "Pengaruh Account Representative (AR) Terhadap Kepatuhan Wajib Pajak Orang Pribadi (KPP Pratama Sidoarjo Utara)." Jurnal Akuntansi AKUNESA 1.1. 
Jurnal Akuntansi dan Keuangan (JAK)

Volume 6, No. 2 Oktober Tahun 2021

Page: 361 - 380

http://ojs.uho.ac.id/index.php/jak-uho/issue/archive

e-ISSN: $2088-4656$

Anonim, Keputusan Menteri Keuangan Republik Indonesia. Nomor 98/KMK.01/2006 Tentang Account Representative pada Kantor Pelayanan Pajak yang Telah Mengimplementasikan Organisasi Modern.

Azuar Juliandi, Irfan, dan Saprinal Manurung. 2014. Metodelogi Penelitian Bisnis. Medan : UMSUPRESS.

Denziana, Angrita, and Handi Sutanto. 2015. "Pengaruh Peran Account Representative Terhadap Tingkat Kepatuhan Wajib Pajak (Studi Kasus pada KPP Pratama di Kota Bandar Lampung)." Jurnal Akuntansi dan Keuangan 6.1.

Gunadi. 2005. Fungsi Pemeriksaan Terhadap Peningkatan Kepatuhan Pajak (Tax Compliance), Vol. 4 No. 5. 4-9

Imam, Ghozali. 2011. "Aplikasi analisis multivariate dengan program IBM SPSS 19." Semarang: Badan Penerbit Universitas Diponegoro.

Resmi „Siti, 2019, Perpajakan Teori dan Kasus Edisi 11. Jakarta : Salemba Empat

Sari, Diana Dr. 2016. Konsep Dasar Perpajakan. Cetakan Kedua. Bandung: PT. Refika Aditama.

Savitri, Faradilla. \& Nuraina, Elva. 2017. Pengaruh Sanksi Perpajakan Terhadap Kepatuhan Wajib Pajak Orang Pribadi di Kantor Pelayanan Pajak Pratama Madiun. Jurnal Equilibrium. Vol. 5. No.1.

Susmita, P. R., \& Supadmi, N. L. 2016. Pengaruh Kualitas Pelayanan, Sanksi Perpajakan, Biaya Kepatuhan Pajak, Dan Penerapan E-Filing Pada Kepatuhan Wajib Pajak, 1239-1269.

Tene, Johanes Herbert, Jullie J. Sondakh, and Jessy DL Warongan. 2017. "Pengaruh pemahaman Wajib Pajak, kesadaran pajak, sanksi perpajakan dan pelayanan fiskus terhadap kepatuhan Wajib Pajak." Jurnal EMBA: Jurnal Riset Ekonomi, Manajemen, Bisnis dan Akuntansi 5.2.

Waluyo. 2017. Perpajakan Indonesia edisi 12, Jakarta: Salemba Empat. 